\title{
MULTIPLIKASI EMBRIO SOMATIS TANAMAN ANGGREK (Dendrobium sp) DENGAN PEMBERIAN KINETIN DAN SUKROSA SECARA IN-VITRO
}

\author{
PEBRA HERIANSYAH ${ }^{{ }^{*}}$ \\ ${ }^{1}$ Prodi Agroteknologi, Fakultas Pertanian, Universitas Islam Kuantan Singingi, Jln . Jl. Gatot Subroto KM 7 , \\ Kebun Nenas, Teluk Kuantan, Kabupaten Kuantan Singingi, Riau 29566, Indonesia \\ *le-mail:hpebra92@gmail.com
}

\begin{abstract}
ABSTRAK
Penelitian ini bertujuan mendapatkan kombinasi konsentrasi Sukrosa dan Kinetin yang memberikan pengaruh terbaik pada eksplan anggrek Dendrobium sp dalam kultur jaringan. Penelitian ini dilaksanakan di Laboratorium Kultur Jaringan Balai Benih Induk Dinas Pertanian dan Peternakan Rovinsi Riau Pekanbaru pada bulan April sampai dengan Juni 2015. Rancangan yang digunakan dalam penelitian Rancangan Acak Lengkap (RAL) faktorial yang terdiri dari dua faktor dan tiga ulangan, faktor pertama adalah pemberian Sukrosa, terdiri dari 4 taraf yaitu : sukrosa $\quad 0,0 \quad \mathrm{~g}^{-1}$, sukrosa $25 \mathrm{~g} \mathrm{~L}^{-1}$, sukrosa 50,0 $\mathrm{g} \mathrm{L}^{-1}$, sukrosa 75,0 $\mathrm{g} \mathrm{L}^{-1}$. Sedangkan faktor yang kedua adalah pemberian Kinetin, terdiri dari empat taraf yaitu : kinetin 0,0 ppm, B1 kinetin 0,1 $\mathrm{mg} \mathrm{L}^{-1}$, kinetin 1,0 $\mathrm{mg} \mathrm{L}^{-1}$, kinetin $10 \mathrm{mg} \mathrm{L}^{-1}$. Interaksi sukrosa dan kinetin berpengaruh nyata terhadap persentase tumbuh eksplan, umur muncul tunas, persentase eksplan membentuk tunas, jumlah tunas, persentase eksplan membentuk akar. dengan perlakuan terbaik $50 \mathrm{~g} \mathrm{~L}^{-1}$ sukrosa dan $1,0 \mathrm{mg} \mathrm{L}^{-1}$ kinetin. Perlakuan terbaik pemberian sukrosa adalah $50 \mathrm{~g} \mathrm{~L}^{-1}$ dan kinetin dengan konsentrasi terbaik $1,0 \mathrm{mg} \mathrm{L}^{-1}$.
\end{abstract}

Kata kunci : Multiplikasi, Sukrosa, Kinetin

\section{ABSTRACT}

The objective of the study was to obtain the combination of sucrose and kinetin concentration reducted in the best effect on Dendrobium explant. This research was conducted in laboratory of tissues culture in Balai Benih Induk Dinas Pertanian and Peternakan Provinsi Riau Pekanbaru from April to June 2015. The experiment was designed using completely randomized design (CRD), factorial consisting of two factors with three replications, the first factor was sucrose with four level respectively $0,25,50,75 \mathrm{~g} \mathrm{~L}^{-1}$ medium. The second factor was kinetin with four level: 0, 0,1, 1,0, $10 \mathrm{mg} \mathrm{L^{-1 }}$. The optimum interaction between effect of sucrose and kinetin for percentage of life explants, age bud formation, percentage of explant forming buds, the number of shoot, a percentage of explant producing root was $50 \mathrm{~g} \mathrm{~L}^{-1}$ sucrose and $1,0 \mathrm{mg} \mathrm{L}^{-1}$ kinetin. Application of sucrose significantly effect age of bud formation, percentage of explant forming buds, number of shoot, shoots high, percentage of explant producing root, number of root, root high, root and shoot ratio (T/R Ratio). Sucrose at $50 \mathrm{~g} \mathrm{~L}^{-1}$ medium being the best consentration and Kinetin 1,0 $\mathrm{mg} \mathrm{L}^{-1}$ being the best consentration.

Keyword: Multiplication, Sucrose, Kinetin.

Diterima 11 September 2018 ; disetujui 27 September 2018

\section{PENDAHULUAN}

Tanaman Anggrek (Dendrobium Sp) anggrek ini akan semakin meningkat, hal ini memiliki prosfek bisnis yang baik jika dilihat tentu membuka peluang besar untuk dari pangsa pasarnya serta banyaknya memproduksi anggrek dalam jumlah besar peminat dari anggrek ini, sehingga atau skala komersial, dan jika dilihat dari memungkinkan jika kedepan peminat jumlah ekspor anggrek pun semakin 
meningkat dengan persyaratan yang amat menuntut keragaman sifat bunga. Sifat dari kualitas bunga untuk kepentingan ekspor ini harus memenuhi patokan dan keragaman sifat yang tinggi.

Perbanyakan tanaman anggrek secara konvensional memiliki masalah fisiologis, karena biji anggrek tidak memiliki endosperm, dan dikondisi alami anggrek biasanya bersimbiosis dengan jamur mikoriza dalam proses perkecambahannya, untuk itu anggrek perlu diperbanyak menggunakan teknik kultur jaringan.

Kultur jaringan merupakan suatu tehnik mengisolasi bagian tanaman, baik berupa organ, jaringan, sel ataupun protoplasma dan selanjutnya mengkultur bagian tanaman tersebut pada media buatan dengan kondisi lingkungan yang steril dan terkendali. Bagian tanaman tersebut dapat beregenerasi hingga membentuk tanaman lengkap (Basri,2004),

Keberhasilan pelaksanaan kultur jaringan antara lain ditentukan oleh pengunaan komposisi media yang sesuai. Hendaryono dan Wijayani (1994) mengemukakan media merupakan faktor penentu dalam perbanyakan tanaman dengan kultur jaringan. Media dasar yang biasa di gunakan dalam kultur jaringan adalah media MS (Murrashige dan Skoog). Menurut Gunawan (1990), dari sekian banyak jenis media dasar yang digunakan dalam teknik kultur jaringan, tampaknya media MS (Murashige-Skoog) mengandung jumlah hara organik yang layak untuk memenuhi kebutuhan banyak jenis sel tanaman dalam kultur jaringan.

Selanjutnya yang perlu diperhatikan adalah kebutuhan zat pengatur tumbuh khususnya kombinasi dan konsentrasi zat pengatur tumbuh yang digunakan. Zat pengatur tumbuh berfungsi merangsang pertumbuhan tanaman, misalnya pertumbuhan akar, tunas, perkecambahan dan sebagainya (Hendaryono \& Wijayani, 1994). Zat pengatur tumbuh yang biasa dan sering digunakan adalah golongan auksin dan sitokinin.
Sitokinin adalah jenis zat pengatur tumbuh yang berperan dalam memacu pembelahan sel, memacu pembentukan organ, menunda penuaan, meningkatkan aktivitas wadah penampung hara, dan memacu perkembangan kuncup sampai keluar. Pada teknik kultur jaringan sitokinin merupakan hormon eksogen yang penting dalam proses morfogenesis pada kultur jaringan. Sitokinin sangat dibutuhkan dalam proses morfogenesis pada kultur jaringan. Yang termasuk dalam golongan sitokinin adalah Kinetin, Zeatin dan Benzil Amino Purin ( BAP ). Sitokinin sangat dibutuhkan dalam proses pembelahan sel dan merangsang inisiasi tunas, penambahan sitokinin kedalam media kultur pada konsentrasi yang tinggi dapat memacu pertumbuhan tunas aksilar dan mereduksi tunas apical dari pucuk utama pada kultur jaringan tanaman berdaun lebar (Salisbury dan Ross, 1995).

Selain zat pengatur tumbuh bahan yang dibutuhkan untuk pertumbuhan eksplan adalah karbohidrat. Menurut (Fardani, 2005) karbohidrat merupakan sumber energi tanaman dalam kultur sebagai pengganti energi yang tidak dapat diperoleh dari fotosintesis. Department of Botany (1999) menjelaskan baha sukrosa adalah gabungan dari glukosa dan fruktosa dengan rumus molekul $\mathrm{C}_{12} \mathrm{H}_{11} \mathrm{O}_{22}$, merupakan golongan disakarida yang dapat larut di dalam air, alkohol maupun eter dan biasanya ditemukan dalam bentuk Kristal. Sukrosa dapat berasal dari sari tebu (tropis) atau dari bit sukrosa (subtropis). Sukrosa jika bereaksi dengan asam atau enzim akan mengikat satu molekul air sehingga molekul disakarida pecah menjadi 2 molekul monosakarida (sukrosa heksosa) yaitu glukosa dan fruktosa.

Sukrosa berperan penting dalam pertumbuhan vegetatif tanaman yang meliputi perkembangan akar, daun dan batang baru. Hal ini terjadi karena pada saat pembelahan sel-sel baru diperlukan karbohidrat dalam jumlah besar untuk membangun dinding-dinding sel yang mengandung protoplasma dan selulosa, sedangkan selusosa dan protoplasma disusun 
sebagian besar oleh gula 2005).

Dalam memacu pertumbuhan embrio somatis tanaman anggrek sukrosa dan kinetin memiliki hubungan yang sangat erat. Embrio samatis tidak akan mengalami organogenesis jika tidak mendapatkan asupan karbohidrat dari penambahan sukrosa, hal ini terjadi karena embrio tidak memiliki energi yang cukup untuk menjalankan proses organogenesis meskipun sitokinin di berikan dengan penambahan kinetin. Sebaliknya jika sitokinin tidak ditambahkan kedalam media

\section{METODE PENELITIAN}

Penelitian ini dilaksanakan di Laboratorium Kultur Jaringan Tanaman Balai Benih Induk Dinas Pertanian dan Peternakan, Kompleks Perkantoran BBI Kelurahan Simpang Tiga, Kecamatan Bukit Raya, Kota Pekanbaru. Penelitian telah dilaksanakan selama empat bulan dari bulan April sampai dengan Agustus 2015.

Bahan yang digunakan dalam penelitian ini adalah eksplan tanaman anggrek Denrobium sp yang telah berumur 3 bulan dari labor kultur jaringan Balai Benih Induk (BBI), sukrosa, kinetin, myoinositol, Arang aktif, bahan kimia Media MurashigeSkoog, aquades steril, Alkohol, tepung agar, gula, IAA, BAP, deterjen, dan bahan-bahan lain yang mendukung penelitian ini. Alat yang digunakan dalam penelitian ini adalah Laminar air flow cabinet, autoclave, timbangan analitik, erlenmeyer, gelas ukur, gelas piala, petridish, jarum injeksi, pipet, pengaduk kaca, pinset, scapel, lampu spritus,

\section{HASIL DAN PEMBAHASAN}

\section{Persentase Hidup Eksplan (\%)}

Dari Tabel 1 dapat dilihat bahwa pada akhir penelitian atau umur 99 HST secara interaksi pemberian konsentrasi sukrosa dan kinetin berpengaruh nyata setelah dianalisis secara statistik dan secara tunggal tidak memberikan pengaruh yang nyata, artinnya tidak ada meskipun sukrosa ditambahkan, maka embriopun tidak akan menunjukkan pertumbuhan yang baik, hal ini disebabkan oleh tidak adanya hormon yang menstimulasi kerja enzim dalam proses pertumbuhan embrio tersebut. Jadi, sukrosa dan kinetin harus ditambahan kedalam media.

Tujuan dilakukan penelitian ini adalah untuk mengetahui pengaruh kombinasi perlakuan kinetin dan sukrosa terhadap multiplikasi embrio somatis Anggrek Dendrobium sp secara in-vitro.

hand sprayer, pisau, $\mathrm{pH}$ meter, botol kultur, kompor gas, lemari

penyimpan bahan kimia, tabung reaksi, labu ukur, gunting, rak kultur, kulkas, ember plastik, alat tulis dan perlengkapan pencucian.

Rancangan yang digunakan dalam penelitian ini adalah Rancangan Acak Lengkap (RAL) faktorial yang terdiri dari dua faktor. Faktor pertama adalah pemberian Sukrosa (Faktor A) yang terdiri dari 4 taraf dan Pemberian Kinetin (Faktor B) yang terdiri dari 4 taraf.

Faktor A terdiri dari 4 taraf yaitu : A0 (Tanpa Pemberian Sukrosa); A1 (Pemberian Sukrosa 25 g liter $^{-1}$ ); A2 (Pemberian Sukrosa $50 \mathrm{~g}$ liter $^{-1}$ ); A3 (Pemberian Sukrosa $75 \mathrm{~g}$ liter $\left.^{-1}\right)$. Faktor B terdiri dari 4 taraf yaitu : B0 (Tanpa Pemberian Kinetin); B1 (Pemberian Kinetin 0,1 ppm liter ${ }^{-1}$ ); B2 (Pemberian Kinetin 1,0 ppm liter ${ }^{-1}$ ); B3 (Pemberian Kinetin 10 ppm liter ${ }^{-1}$ ).

perbedaan pemberian konsentrasi tersebut dan jika dilihat dari angka terjadinya perbedaan yang signifikan, yaitu : $100 \%$, $91,67 \%$ dan $0 \%$ atau mati. Pemberian sukrosa tunggal tidak berpengaruh nyata, tetapi tiap perlakuan hasil angka yang diperoleh dalam persentase hidup eksplan berbeda nyata. Angka yang paling tinggi dalam persentase hidup eksplan adalah 
Tabel 1. Rerata persentase Hidup Eksplan Anggrek Dendrobium sp dengan perlakuan Sukrosa dan Kinetin pada umur 99 Hari Setelah Disubkultur $(\%)$

\begin{tabular}{|c|c|c|c|c|c|}
\hline \multirow{2}{*}{$\begin{array}{l}\text { Pemberian Sukrosa (g } \\
\text { liter }^{-1} \text { ) }\end{array}$} & \multicolumn{4}{|c|}{ Pemberian Kinetin (ppm) } & \multirow{2}{*}{ Rerata A } \\
\hline & B0 $(0,0)$ & $\mathrm{B} 1(0,1)$ & B2 $(1,0)$ & B3 $(10,0)$ & \\
\hline $\mathrm{A} 0(0)$ & $100.00 \mathrm{a}$ & $100.00 \mathrm{a}$ & $100.00 \mathrm{a}$ & $100.00 \mathrm{a}$ & 100.00 \\
\hline A1 (25) & $100.00 \mathrm{a}$ & $100.00 \mathrm{a}$ & $100.00 \mathrm{a}$ & $100.00 \mathrm{a}$ & 100.00 \\
\hline A2 (50) & $100.00 \mathrm{a}$ & $100.00 \mathrm{a}$ & $100.00 \mathrm{a}$ & $100.00 \mathrm{a}$ & 100.00 \\
\hline A3 (75) & $100.00 \mathrm{a}$ & $100.00 \mathrm{a}$ & $100.00 \mathrm{a}$ & $91.67 \mathrm{~b}$ & 97.92 \\
\hline Rerata B & 100.00 & 100.00 & 100.00 & 97.92 & \\
\hline
\end{tabular}

KK $=3,63 \quad$ BNJ A \& B $=0,4 \quad$ BNJ A B $=1,09$

Angka - angka pada baris dan kolom yang diikuti dengan huruf yang sama tidak berbeda nyata menurut Uji BNJ pada Taraf $5 \%$

$100 \%$ yang terdapat pada perlakuan A0 (Tanpa sukrosa), A1 (25 $\left.{ }^{\mathrm{g} \text { liter-1 }}\right)$,dan A2 (50 mg liter $\left.{ }^{-1}\right)$. dan perlakuan yang paling rendah A3 (75 $\left.\mathrm{mg} \mathrm{liter}^{-1}\right)$ dengan persentase hidup eksplan 97,92\%.

Dalam perlakuan sukrosa tidak berpengaruh terhadap persentase tumbuh eksplan, artinya tanpa pemberian sukrosa pun eksplan anggrek Dendrobium sp masih bisa tumbuh dan berkembang, hal ini dikarenakan pada media telah ditambahkan pisang raja yang memiliki kandungan karbohidrat yang cukup tinggi sehingga mencukupi kebutuhan energi eksplan untuk tumbuh dan berkembang,

Selain faktor karbohidrat yang menjadi sumber energi bagi embrio somatis, eksplan anggrek Denrobium $\mathrm{sp}$ juga memerlukan ZPT yang berperan dalam memacu pertumbuhan dan perkembangan embrio somatis. Karena pentingnya peranan ZPT untuk pertumbuhan eksplan, maka dalam media ditambahkan kinetin untuk meningkatkan pertumbuhan eksplan (Miller et al, 1956). Eksplan anggrek menginginkan

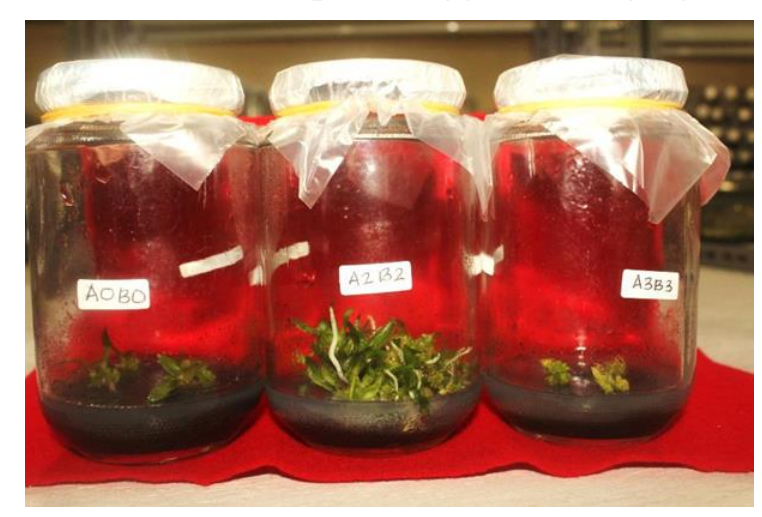

Gambar 01. Ekplan berumur 99 hari konsentrasi kinetin yang optimum pada konsentrasi 0,1 ppm, namun pada konsentrasi mencapai 10 ppm hal ini akan menghambat pertumbuhan embrio somatis, begitu juga pada media yang tidak ditambahkan kinetin, maka dapat dilihat bahwa eksplan tidak melakukan pembelahan sel yang optimum sehingga 1 embrio hanya menumbuhkan 1 tunas dalam waktu yang lambat pula.

Keberhasilan sebuah penelitian invitro selain penambahan nutrisi dan zat pengatur tumbuh yang tepat, serta mengkondisikan ruang kultur jaringan yang bebas bakteri dan jamur. Dan juga harus aseptic dalam kultur jaringan untuk menghindari terjadinya kontaminasi yang dapat menurunkan produksi kultur jaringan tanaman. Conger (1998) mengemukakan bahwa keberhasilan dalam teknik in-vitro dipengaruhi oleh beberapa faktor yang meliputi media kultur dan nutrisi yang terkandung didalamnya, bahan tanaman atau eksplan, keadaan lingkungan kultur yang aseptic dan penambahan zat pengatur tumbuh yang digunakan.

\section{Umur Muncul Tunas (Hari)}

Berdasarkan hasil analisis sidik ragam dari data hasil pengamatan parameter Umur muncul Tunas, menunjukkan bahwa interaksi antara pemberian konsentrasi Sukrosa dan Kinetin berpengaruh nyata terhadap Umur muncul tunas. Pengaruh utama konsentrasi Sukrosa, berpengaruh nyata terhadap Umur muncul tunas dan pengaruh utama 
Tabel 2. Rerata Umur Muncul Tunas (HST) Eksplan Anggrek Dendrobium sp dengan perlakuan konsentrasi sukrosa pada umur 80 Hari Setelah Disubkultur

\begin{tabular}{cccccc}
\hline \multirow{2}{*}{$\begin{array}{c}\text { Konsentrasi Sukrosa } \\
\left(\text { ( liter }^{-1}\right)\end{array}$} & \multicolumn{3}{c}{ Konsentrasi Kinetin (ppm) } & \multirow{2}{*}{ Rerata A } \\
\cline { 2 - 5 } A0 (0) & B0 $(0,0)$ & B1 $(0,1)$ & B2 (1,0) & B3 (10) & $71.22 \mathrm{~d}$ \\
A1 (25) & $63.67 \mathrm{k}$ & $71.78 \mathrm{j}$ & $71.67 \mathrm{j}$ & $67.78 \mathrm{i}$ & $55.36 \mathrm{~b}$ \\
A2 (50) & $41.33 \mathrm{c}$ & $36.78 \mathrm{~b}$ & $28.00 \mathrm{a}$ & $42.33 \mathrm{c}$ & $37.11 \mathrm{a}$ \\
A3 (75) & $57.22 \mathrm{f}$ & $65.22 \mathrm{~h}$ & $70.67 \mathrm{i}$ & 80.221 & $68.33 \mathrm{c}$ \\
Rerata B & $58.67 \mathrm{c}$ & $57.81 \mathrm{~b}$ & $55.61 \mathrm{a}$ & $59.94 \mathrm{~d}$ & \\
\hline
\end{tabular}

$\mathrm{KK}=0,63 \% \quad$ BNJ A \& B $=0,40 \quad \mathrm{BNJ} \mathrm{AB}=1,09$

Angka - angka pada baris dan kolom yang diikuti dengan huruf yang sama tidak berbeda nyata menurut Uji BNJ pada Taraf $5 \%$

konsentrasi Kinetin juga berpengaruh nyata terhadap Umur muncul tunas.

Tabel 2, dapat dilihat bahwa hasil tercepat ekplan anggrek (Dendrobium $\mathrm{sp}$ ) mengeluarkan tunas adalah A2B2 (50 g liter ${ }^{-1}$ Sukrosa dan 1.0 ppm Kinetin) yaitu 28,00 HSTdan perlakuan yang lambat mengeluarkan tunas adalah A3B3 (g liter ${ }^{-1}$ Sukrosa dan 10 ppm Kinetin) yaitu 80,22 HST. Hal ini menggambarkan bahwa eksplan anggrek Dendrobium sp untuk pertumbuhan tunasnya membutuhkan sukrosa pada konsentrasi $50 \mathrm{~g} \mathrm{liter}^{-1}$ dan sedangkan kinetin pada konsentrasi yang rendah yaitu 1,0 ppm, sedangkan jika konsentrasi yang tinggi kedua faktor ini akan menyebabkan embrio menjadi kerdil.

Semakin cepat tunas terbentuk maka akan semakin meningkat pula nutrisi yang diserap oleh eksplan sehingga akan mempercepat pembentukan eksplan membentuk individu baru, karena semua eksplan masih didalam botol yang merupakan sumber nutrisi adalah yang terdapat pada media agar tersebut. Sehingga nutrisi yang tersedia merupakan faktor utama dalam menunjang perkembangan eksplan untuk membentuk tanaman baru.

Pemberian perlakuan secara interaksi menghsilkan umur muncul tunas lebih cepat karena perlakuan yang diberikan menyebebkan diferensiasi sel-sel kearah pembentukan organ dan jaringan yang lebih terarah. Ini membuktikan bahwa pertumbuhan dan morfogenesis eksplan secara in-vitro dikendalikan oleh keseimbangan interaksi antara zat pengatur tumbuh yang ada dalam eksplan maupun yang diserap pada media kultur.

Berhasilnya pertumbuhan tunas selain ditentukan oleh jenis dan kadar hormon pertumbuhan, juga bergantung pada sumber jaringan serta kadar medium hara. Unsur hara yang diserap tersedia bagi tanaman mendorong aktivitas metabolisme dalam jaringan tanaman tersebut dan menyebabkan sel-sel tanaman membelah. Secara umum, tujuan perbanyakan secara in-vitro adalah regenerasi yang diharapkan menghasilkan planlet. Proses ini diawali dengan terbentuknya tunas yang tumbuh dan berkembang karena pengaruh adanya media dan zat pengatur tumbuh (Gunawan, 1998)

Secara tunggal pemberian konsentrasi sukrosa A2 (50 g liter $\left.{ }^{-1}\right)$ berbeda nyata dengan A0 (0 g liter $\left.{ }^{-1}\right)$, A1 (25 $\left.\mathrm{g} \mathrm{liter}^{-1}\right)$,dan B3 (75 g liter $\left.^{-1}\right)$. perlakuan sukrosa yang paling cepat bertunas adalah A2 yaitu 37,11 HST diikuti oleh A1 dengan umur muncul tunas 55,36 HST kemudian A3 dengan umur muncul tunas 68,33 HST dan paling rendah adalah A0 dengan umur muncul tunas 71,22 HST.

Pemberian sukrosa dengan konsentrasi yang tinggi menyebabkan terganggunya pertumbuhan tunas dan tanpa pemberian sukrosa juga memperlambat munculnya tunas pada embrio. Jadi dapat disimpulkan, bahwa tanpa pemberian sukrosa, pemberian sukrosa dalam 
konsentrasi tinggi (75 g liter $\left.{ }^{-1}\right)$ dapat menghambat pemunculan tunas eksplan anggrek Dendrobium sp, sedang dengan konsentrasi sedang (50 $\mathrm{g}$ liter $\left.^{-1}\right)$ dapat memacu pemunculan tunas pada embrio somatis anggrek Dendrobium sp.

Dari hasil penelitian ini jika dibandingkan dengan penelitian sebelum yang dilakukan oleh Setriana (2012), yang melakukan penelitian pada embrio somatis anggrek vanda dengan penambahan glukosa, Beliau menyimpulkan bahwa konsentrasi terbaik untuk memunculkan tunas anggrek vanda adalah pada konsentrasi $25 \mathrm{~g}$ liter $^{-1}$ namun pada konsentrasi $50 \mathrm{~g} \mathrm{liter}^{-1}$ juga tidak jauh berbeda dengan perlakuan terbaik, bedanya hanya berkisar 2 HST, sedangkan pada penelitian ini embrio somatis anggrek Dendrobium sp justru menunjukkan bahwa konsentrasi $50^{\mathrm{g} \text { liter-1 }}$ sukrosa menunjukkan umur muncul tunas terbaik.

Menurut Gunawan (1992) karbohidrat merupakan salah satu komponen yang dibutuhkan oleh berbagai macam tumbuhan dalam pemenuhan kebutuhan karbon dan energi. Sukrosa merupakan sumber karbon yang sering digunakan. Sukrosa berperan dalam menghasilkan energi dalam proses respirasi dan sebagai bahan pembentuk sel baru. Glukosa, maltosa dan rafinosa juga dapat digunakan sebagai pengganti sukrosa dalam menghasilkan energi akan tetapi kurang efektif.

Dari tabel juga dapat dilihat bahwa pemberian konsentrasi Kinetin B2 (1,0 ppm) berbeda nyata dengan B0 (0 ppm), B1 (0,1 ppm),dan B3 (10,0 ppm). perlakuan Kinetin yang paling cepat bertunas adalah B2 yaitu 55.61 HST diikuti oleh B1 dengan umur muncul tunas 57,81 HST kemudian A0 dengan umur muncul tunas 58,67 HST dan paling rendah adalah A3 dengan umur muncul tunas 59,94 HST. Angka tertinggi pada umur muncul tunas dihasilkan dengan pemberian perlakuan konsentrasi Kinetin B2 (1,0 ppm), dengan pertumbuhan tunas yang diawali dengan pembentukan protocorm like bodies yang kemudian tumbuh membentuk tunas dalam jumlah yang banyak hingga mencapai 28 buah tunas, jika dilihat dan dibandingkan dengan perlakuan B0, B1, dan B3 yang tunasnya juga membentuk plb namun ukuran jauh lebih kecil dibandingkan perlakuan B2 sehingga ketika tunas muncul jumlah rerata jauh lebih kecil.

Tetapi untuk perlakuan B3 (10 ppm) hanya muncul tunas sedikit saja yang pertumbuhannya sangat lambat. Hal ini disebabkan karena konsentrasi kinetin yang terlalu tinggi akan menyebabkan terganggu proses metabolisme sel pada embrio.

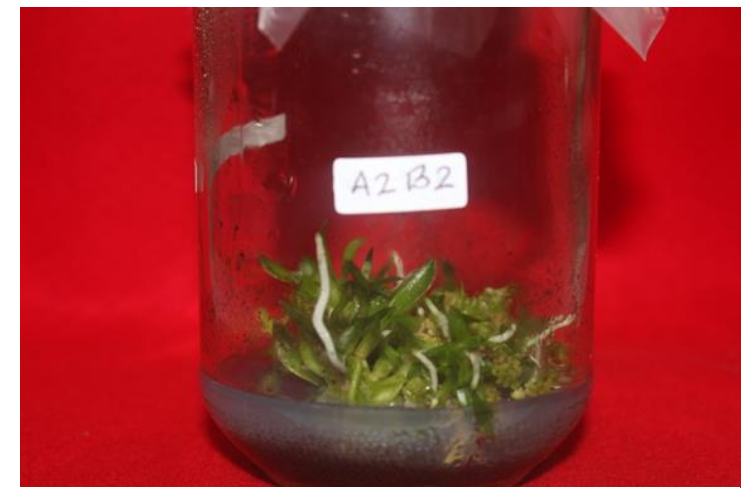

Gambar 02. Eksplan dengan umur muncul tunas tercepat (kinetin 1,0 ppm dansukrosa $50 \mathrm{~g}$ liter $^{-1}$

\section{Persentase Tumbuh Tunas (\%)}

Berdasarkan hasil analisis sidik ragam dari data hasil pengamatan parameter persentase tumbuh tunas, menunjukkan bahwa interaksi antara pemberian konsentrasi Sukrosa dan Kinetin berpengaruh nyata terhadap persentase tumbuh tunas. Pengaruh utama konsentrasi Sukrosa, berpengaruh nyata terhadap persentase tumbuh tunas dan pengaruh utama konsentrasi Kinetin juga berpengaruh nyata terhadap persentase tumbuh tunas

Pemberian konsentrasi sukrosa tidak melebihi 50 g liter ${ }^{-1}$ dan konsentrasi kinetin tidak lebih dari 1,0 ppm, jika kedua faktor ini diberikan pada konsentrasi tinggi maka eksplan akan mengalami penurunan persentase tunas eksplan, seperti pada perlakuan A3B3 (Pemberian sukrosa $75 \mathrm{~g}$ liter $^{-1}$. dan Kinetin $10 \mathrm{ppm}$ ) yang persentase tumbuh eksplannya adalah $50 \%$. 
Tabel 3. Rerata Persentase Tumbuh Tunas eksplan Anggrek dengan konsentrasi Sukrosa dan konsentrasi Kinetin pada umur 80 Hari Setelah Disubkultur (\%)

\begin{tabular}{cccccc}
\hline \multirow{2}{*}{$\begin{array}{c}\text { Konsentrasi Sukrosa } \\
\text { (gram) }\end{array}$} & \multicolumn{4}{c}{ Konsentrasi kinetin (ppm) } & \multirow{2}{*}{ Rerata A } \\
\cline { 2 - 5 } A0 (0) & $100.00 \mathrm{a}$ & $100.00 \mathrm{a}$ & $100.00 \mathrm{a}$ & $100.00 \mathrm{a}$ & $100.00 \mathrm{a}$ \\
A1 (25) & $100.00 \mathrm{a}$ & $100.00 \mathrm{a}$ & $100.00 \mathrm{a}$ & $100.00 \mathrm{a}$ & $100.00 \mathrm{a}$ \\
A2 (50) & $100.00 \mathrm{a}$ & $100.00 \mathrm{a}$ & $100.00 \mathrm{a}$ & $100.00 \mathrm{a}$ & $100.00 \mathrm{a}$ \\
A3 (75) & $100.00 \mathrm{a}$ & $100.00 \mathrm{a}$ & $66.67 \mathrm{~b}$ & $50.00 \mathrm{c}$ & $79.17 \mathrm{~b}$ \\
Rerata B & $100.00 \mathrm{a}$ & $100.00 \mathrm{a}$ & $91.67 \mathrm{~b}$ & $87.50 \mathrm{c}$ & \\
\hline
\end{tabular}

KK $=3,81 \% \quad$ BNJ A \& B $=3,95 \quad$ BNJ AB $=10,77$

Angka - angka pada baris dan kolom yang diikuti dengan huruf yang sama tidak berbeda nyata menurut Uji BNJ pada Taraf $5 \%$

Pemberian konsentrasi sukrosa secara tunggal berpengaruh nyata terhadap persentase tumbuh tunas.perlakuan yang paling tinggi persentase tumbuh tunasnya adalah perlakuan A0 $\left(0 \mathrm{~g} \mathrm{liter}^{-1}\right)$, A1 $(25 \mathrm{~g}$ liter $\left.^{-1}\right)$, dan A2 (50 g liter $\left.{ }^{-1}\right)$ dengan persentase tumbuh tunasnya $100 \%$ dan persentase tumbuh tunas terendah terdapat pada perlakuan A3 (75 $\left.\mathrm{g} \mathrm{liter}^{-1}\right)$ yaitu 79,17 $\%$.

Sukrosa merupakan sumber energi yang terhidrolisis secara cepat menjadi heksosa (glukosa dan fruktosa) oleh enzim invertase dinding sel. Glukosa dan fruktosa hasil hidrolisis sukrosa masuk ke dalam sel secara terpisah. Kedua monosakarida tersebut digunakan sel untuk metabolisme, selanjutnya digunakan sebagai sumber energi dan sumber karbon. (Krook, Vreughdenhil, Dijkema dan van der Plas, 1998). Menurut setriana (2012), menyatakan bahwa konsentrasi yang cocok untuk sumber karbohidrat yang ditambahkan pada media berkisar antara 25-50 $\mathrm{g} \mathrm{liter}^{-1}$.

Perlakuan B0 dan B1 berbeda nyata dengan perlakuan B2 dan B3. Tetapi dalam

\section{Tinggi Tunas (cm)}

Berdasarkan hasil analisis sidik ragam dari data hasil pengamatan parameter tinggi tunas, menunjukkan bahwa interaksi antara pemberian konsentrasi Sukrosa dan Kinetin angka perlakuan yang paling tinggi persentase tumbuh tunasnya adalah B0 (0 ppm0 dan B1 (0,1 ppm) yaitu $100 \%$ dan diikuti oleh perlakuan B2 (1,0 ppm) yaitu 91,67\% dan paling rendah adalah perlakuan B3 (10 ppm) dengan persentase tumbuh tunasnya adalah $87,50 \%$.

Pemberian kinetin pada konsentrasi yang rendah hingga $1,0 \mathrm{ppm}$ mampu meningkatkan persentase tunas yang baik. Ini berarti eksplan anggrek Dendrobium sp menginginkan media dengan tambahan kinetin yang rendah berkisar antara $0,1-1,0$ ppm dan pada A0 mengapa persentase tunasnya juga baik, hal itu dikarenakan pada media seluruhnya ditambahkan ekstrak pisang raja yang juga mengandung sitokinin.

Kinetin merupakan golongan sitokinin yang berperan memacu pembelahan sel, memacu pembentukan organ, menunda penuaan, meningkatkan aktivitas penampung hara, dan memacu perkembangan kuncup sampai keluar. Pada teknik kultur jaringan sitokinin merupakan hormon eksogen yang penting dalam proses morfogenesis pada kultur jaringan (Salisbury dan Ross 1995).

tidak berpengaruh nyata terhadap tinggi tunas. Pengaruh utama konsentrasi Sukrosa, berpengaruh nyata terhadap tinggi tunas dan pengaruh utama konsentrasi Kinetin juga berpengaruh nyata terhadap tinggi tunas. 
Tabel 4. Rerata Tinggi Tunas pada Eksplan Anggrek Dendrobium sp dengan perlakuan Sukrosa dan Kinetin pada umur 99 Hari Setelah Disubkultur $(\mathrm{cm})$

\begin{tabular}{|c|c|c|c|c|c|}
\hline \multirow{2}{*}{$\begin{array}{l}\text { Konsentrasi Sukrosa } \\
\text { (gram) }\end{array}$} & \multicolumn{4}{|c|}{ Konsentrasi Kinetin (ppm) } & \multirow{2}{*}{ Rerata A } \\
\hline & B0 $(0,0)$ & $\mathrm{B} 1(0,1)$ & B2 $(1,0)$ & B3 $(10,0)$ & \\
\hline $\mathrm{A} 0(0)$ & 1.03 & 1.17 & 1.17 & 1.18 & $1.14 \mathrm{c}$ \\
\hline A1 (25) & 1.20 & 1.23 & 1.25 & 1.27 & $1.24 \mathrm{~b}$ \\
\hline A2 (50) & 1.36 & 1.68 & 1.95 & 1.33 & $1.58 \mathrm{a}$ \\
\hline A3 (75) & 0.91 & 0.87 & 0.70 & 0.37 & $0.71 \mathrm{~d}$ \\
\hline Rerata B & $1.13 \mathrm{~b}$ & $1.24 \mathrm{a}$ & $1.27 \mathrm{a}$ & $1.04 \mathrm{~b}$ & \\
\hline
\end{tabular}

$\mathrm{KK}=1,71$

BNJ A \& B $=0,02$

Angka - angka pada baris dan kolom yang diikuti dengan huruf yang sama tidak berbeda nyata menurut Uji BNJ pada Taraf $5 \%$

Tabel 6 dapat dilihat bahwa secara interaksi tinggi tunas tidak berpengaruh nyata. Dilihat dari angka terdapat perbedaan dan angka yang paling tinggi adalah perlakuan A2B2 (Sukrosa $50 \mathrm{~g}$ liter $^{-1}$ dan Kinetin 1,0 ppm) dengan tinggi tunas $1,95 \mathrm{~cm}$ dan perlakuan dengan jumlah tunas terendah adalah perlakuan A3B3 (Sukrosa $75 \mathrm{~g} \mathrm{liter}^{-1}$ dan Kinetin 10 ppm) dengan tinggi tunas $0,37 \mathrm{~cm}$.

Perlakuan A2B0,A2B1, A2B2 pertumbuhannya cukup baik karena konsentrasi sukrosa tidak melebihi $50 \mathrm{~g}$ liter $^{-1}$ dan konsentrasi kinetin tidak lebih dari 1,0 ppm, jika kedua faktor ini diberikan pada konsentrasi tinggi maka eksplan akan mengalami penurunan tinggi tunas eksplan, seperti pada perlakuan A3B3 (Pemberian sukrosa $75 \mathrm{~g} \mathrm{liter}^{-1} \mathrm{dan}$ Kinetin $10 \mathrm{ppm}$ ) yang tinggi tunasnya adalah $0,37 \mathrm{~cm}$.

Pemberian konsentrasi sukrosa secara tunggal berpengaruh nyata terhadap tinggi tunas. Perlakuan terbaik dengan tinggi tunasnya adalah perlakuan A2 (50 $\mathrm{g} \mathrm{liter}^{-1}$ ) yaitu $1,58 \mathrm{~cm}$, kemudian A1 $\left(25 \mathrm{~g} \mathrm{liter}^{-1}\right)$ yaitu $1,24 \mathrm{~cm}$ dan A2 $(50 \mathrm{~g}$ liter ${ }^{-1}$ ) dengan tinggi tunasnya $1,14 \mathrm{~cm}$ serta tinggi tunas terendah terdapat pada perlakuan A3 (75 g liter $\left.{ }^{-1}\right)$ yaitu $0,71 \mathrm{~cm}$.

Menurut George \& Sherrington (1984) sukrosa merupakan sumber karbon penting yang digunakan sebagai penyusun sel. Dengan adanya sukrosa yang cukup,

maka pembelahan, pembesaran dan diferensiasi sel selanjutnya dapat berlangsung dengan baik. 1-2\% sukrosa, $2 \%$ fruktosa, $1-3 \%$

glukosa serta $2 \%$ gula pasir memberikan hasil yang lebih baik terhadap pertumbuhan planlet anggrek Dendrobium dibandingkan media tanpa sumber karbohidrat sederhana.

Perlakuan B2 dan B1 berbeda nyata dengan perlakuan B0 dan B3. Tetapi dalam angka perlakuan terbaik dengan tinggi tunasnya adalah B2 (1,0 ppm) yaitu $1,24 \mathrm{~cm}$ dan diikuti oleh perlakuan B2 (1,0 ppm) yaitu $1,24 \mathrm{~cm}$ dan paling rendah adalah perlakuan B3 (10 ppm) dengan tinggi tunasnya adalah $1,04 \mathrm{~cm}$.

Pemberian kinetin pada konsentrasi yang rendah hingga $1,0 \mathrm{ppm}$ mampu meningkatkan tinggi tunas yang baik. Ini berarti eksplan anggrek Dendrobium sp menginginkan media dengan tambahan kinetin yang rendah berkisar antara $0,1-$ 1,0 ppm dan pada A0 tanaman mengalami kekurangan hormon sitokinin sementara pada A3 tanaman kelebihan hormon sitokinin.

Menurut Wattimena (1995), pengaruh sitokinin dalam kultur jaringan tanaman meningkatkan poliferasi tunas ketiak. Sitokinin dapat menghambat dominansi apikal dan merangsang poliferasi tunas ketiak dan munculnya tunastunas ketiak baru. More dalam 
Wahidah (2011) bahwa hormon Kinetin dapat mempengaruhi proses perkembangan tanaman pada konsentrasi rendah dan pada konsentrasi tinggi dapat menghambat pertumbuhan.

\section{Jumlah Tunas (buah)}

Berdasarkan hasil analisis sidik ragam dari data hasil pengamatan parameter jumlah tunas, menunjukkan bahwa interaksi antara pemberian konsentrasi Sukrosa dan Kinetin berpengaruh nyata terhadap jumlah tunas. Pengaruh utama konsentrasi Sukrosa, berpengaruh nyata terhadap jumlah tunas dan pengaruh utama konsentrasi Kinetin juga berpengaruh nyata terhadap jumlah tunas. diberikan pada konsentrasi tinggi maka eksplan akan mengalami penurunan tinggi tunas eksplan, seperti pada perlakuan A3B3 (Pemberian sukrosa $75 \mathrm{~g}$ liter $^{-1} \mathrm{dan}$ Kinetin $10 \mathrm{ppm})$ yang jumlah tunasnya adalah $3,11 \mathrm{~cm}$.

Perbedaan jumlah tunas yang terbentuk sebagai bentuk adanya pengaruh kombinasi sukrosa dan kinetin yang ditambahkan ke dalam media.Menurut Wattimena (1995), pengaruh sitokinin dalam kultur jaringan tanaman meningkatkan poliferasi tunas ketiak. Sitokinin dapat menghambat dominansi apikal dan merangsang poliferasi tunas ketiak dan munculnya tunastunas ketiak baru (Puspaningtyas, 1988). Adanya sukrosa yang ditambahkan ke dalam media

Tabel 5. Rerata Jumlah Tunas pada Eksplan Anggrek Dendrobium sp dengan perlakuan Sukrosa dan Kinetin pada umur 99 Hari Setelah Disubkultur (buah)

\begin{tabular}{cccccc}
\hline \multirow{2}{*}{$\begin{array}{c}\text { Konsentrasi Sukrosa } \\
\text { gram })\end{array}$} & B0 $(0,0)$ & B1 $(0,1)$ & B2 $(1,0)$ & B3 $(10,00)$ & Rerata A \\
\cline { 2 - 5 } A0 (0) & 2.111 & $4.11 \mathrm{j}$ & $5.11 \mathrm{i}$ & $7.11 \mathrm{~g}$ & $4.61 \mathrm{c}$ \\
\hline A1 (25) & $7.56 \mathrm{~g}$ & $10.11 \mathrm{f}$ & $11.11 \mathrm{e}$ & $12.44 \mathrm{~d}$ & $10.31 \mathrm{~b}$ \\
\hline A2 (50) & $16.56 \mathrm{c}$ & $21.11 \mathrm{~b}$ & $26.11 \mathrm{a}$ & $17.11 \mathrm{c}$ & $20.22 \mathrm{a}$ \\
\hline A3 (75) & $6.00 \mathrm{~h}$ & $4.56 \mathrm{j}$ & $4.67 \mathrm{j}$ & $3.11 \mathrm{k}$ & $4.58 \mathrm{c}$ \\
\hline Rerata B & $8.06 \mathrm{c}$ & $9.97 \mathrm{~b}$ & $11.75 \mathrm{a}$ & $9.94 \mathrm{~b}$ & \\
\hline KK = 1,81 \% & BNJ A \& B = 0,20 & BNJ AB = 0,54 & & \\
\hline
\end{tabular}

Angka - angka pada baris dan kolom yang diikuti dengan huruf yang sama tidak berbeda nyata menurut Uji BNJ pada taraf 5\%

Dari Tabel 5 dapat dilihat bahwa secara interaksi jumlah tunas berpengaruh nyata. Dilihat dari angka terdapat perbedaan dan angka yang paling tinggi adalah perlakuan A2B2 (Sukrosa $50^{\mathrm{g} \text { liter-1 }}$ dan Kinetin 1,0 ppm) dengan jumlah tunas 26,11 buah dan perlakuan dengan jumlah tunas terendah adalah perlakuan A0B0 (Sukrosa 0 g liter ${ }^{-1}$ dan Kinetin 0 ppm) dengan jumlah tunas 2,11 buah.

Perlakuan A2B0,A2B1, A2B2 pertumbuhannya cukup baik karena konsentrasi sukrosa tidak melebihi $50 \mathrm{~g}$ liter $^{-1}$ dan konsentrasi kinetin tidak lebih dari 1,0 ppm, jika kedua faktor ini sebagai sumber karbon dan sumber energi yang digunakan tanaman untuk tumbuh. Sukrosa memiliki beberapa peran penting dalam media, yaitu sebagai sumber karbon, sumber energi, pengatur tekanan osmotik, mengatur stabilisasi membran, dan berperan sebagai pelindung terhadap stres. Peran sukrosa dalam mengatur tekanan osmotik mempengaruhi kemampuan jaringan dalam penyerapan air dari media ke dalam tanaman

Pemberian konsentrasi sukrosa secara tunggal berpengaruh nyata terhadap tinggi tunas. Perlakuan terbaik dengan jumlah tunasnya adalah perlakuan A2 
(50 g liter $^{-1}$ ) yaitu 20,22 cm, kemudian diikuti oleh A1 (25 g liter ${ }^{-1}$ ) yaitu 10,31 $\mathrm{cm}$ dan A0 (0 $\left.\mathrm{g}_{\text {liter }}{ }^{-1}\right)$ dengan jumlah tunasnya 4,61 buah serta jumlah tunas terendah terdapat pada perlakuan A3 (75 g liter $^{-1}$ ) yaitu 4,58 buah.

Menurut Srilestari (2005), pada media yang banyak mengandung sukrosa akan lebih pekat dari pada yang sedikit mengandung sukrosa. Media dengan konsentrasi pekat berarti banyak terdapat molekul-molekul, sehingga arah gerakan difusi ialah ke tempat yang kekurangan molekul atau yang berkonsentrasi rendah. Keadaan demikian menyebabkan sel-sel pada jaringan eksplan yang ditumbuhkan pada media dengan penambahan sukrosa tinggi dapat lebih cepat menerima unsurunsur hara yang diperlukan bagi perkembangannya.

Perlakuan B2 berbeda nyata dengan perlakuan B1, B3 dan B0. Tetapi dalam angka perlakuan terbaik dengan jumlah tunasnya adalah B2 (1,0 ppm) yaitu 11,75 buah dan eloanjutnya diikuti oleh perlakuan B1 (1,0 ppm) yaitu $\quad 9,97$ $\mathrm{cm}$ dan paling rendah adalah perlakuan B0 (0 ppm) dengan jumlah tunasnya adalah 8,06 buah.

Pemberian kinetin pada konsentrasi yang rendah hingga 1,0 ppm mampu meningkatkan jumlah tunas yang baik. Ini berarti eksplan anggrek Dendrobium sp menginginkan media dengan tambahan kinetin yang rendah berkisar antara 1,0 ppm dan pada A0 tanaman mengalami kekurangan hormon sitokinin sementara pada A3 tanaman kelebihan hormon sitokinin.

Dalam proses metabolisme kinetin terlibat dalam proses pengaturan aktivitas enzim yang mensintesis tepung terutama enzim phosporylase dan sintetase tepung (Gunawan,1987). Menurut More dalam Wahidah (2011) bahwa hormon Kinetin dapat mempengaruhi proses perkembangan tanaman pada konsentrasi rendah dan pada konsentrasi tinggi dapat menghambat pertumbuhan

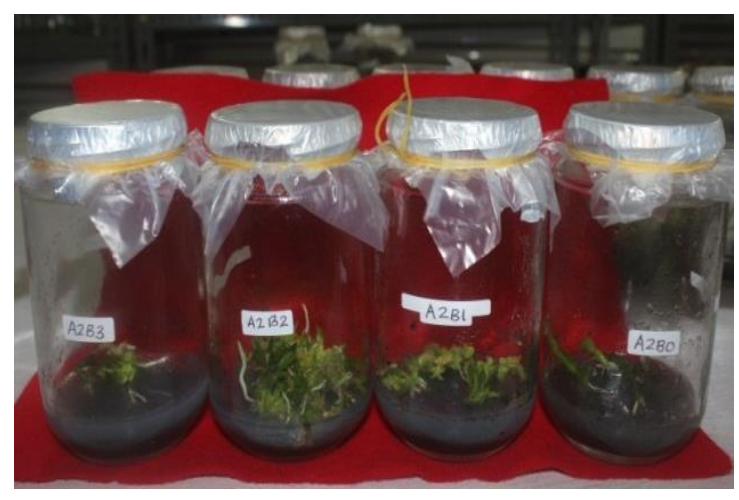

Gambar 05. (Kinetin 1,0 ppm dan sukrosa $50 \mathrm{mg}$ liter $^{-1}$ ) dengan jumlah tunas terbanyak

\section{KESIMPULAN}

Dari hasil penelitian yang telah dilakukan dapat diambil kesimpulan, bahwa Interaksi Sukrosa dan kinetin berpengaruh nyata terhadap persentase tumbuh eksplan, umur muncul tunas, persentase eksplan membentuk tunas, jumlah tunas, persentase eksplan membentuk akar pada tanaman anggrek Dendrobium sp. Dengan perlakuan terbaik $50 \mathrm{~g}$ liter $^{-1}$ Sukrosa dan 1,0 ppm Kinetin. Pemberian Sukrosa berpengaruh nyata terhadap umur muncul tunas, persentase eksplan membentuk tunas, jumlah tunas, tinggi tunas, persentase eksplan membentuk akar, jumlah akar, panjang akar, nisbah akar-tunas (T/R Rasio) pada tanaman anggrek Dendrobium sp. Dengan konsentrasi terbaik $50 \mathrm{~g} \mathrm{liter}^{-1}$. Pemberian Kinetin berpengaruh nyata terhadap umur muncul tunas, persentase eksplan membentuk tunas, jumlah tunas, tinggi tunas, persentase eksplan membentuk akar, jumlah akar, panjang akar, nisbah akar -tunas (T/R rasio) pada tanaman anggrek Dendrobium sp. Dengan konsentrasi terbaik 1,0 ppm 


\section{DAFTAR PUSTAKA}

Agrawal, KC 1999, Physiology and Hendaryono, D. P. S. dan A. Wijayani. 1994. biochemistry of respiration, Agro Botanical Publishers, New Delhi.

Aini. J.2005. Aplikasi Beberapa Taraf Konsentrasi Kinetin Pada Berbagai Sumber Eksplan Khrisan secara Invitro. $\quad \mathrm{http} / / \mathrm{www}$. bdpunib.org;37 halaman.

Teknik Kultur Jaringan, Pengenalan dan petunjuk Perbanyakan Tanaman Secara Vegetatif Modern. Kanisius. Jogjakarta.

Hidayat. 2007. Induksi Pertumbuhan Eksplan Endosperm Ulin dengan IAA dan Kinetin. Agritop. 26 (4): 147 - 152.

Arditti, J \& Ernst, R 1993, Micropropagation of orchids, John Wiley \& Sons. Inc., New York.

Ashari 1995, Perbanyakan Vegetatif pada Anggrek. Kanisius. Jakarta.

Basri, Z. 2004. Kultur Jaringan Tanaman. Universitas Tadulako Press. Palu.

Cheremisinofff \&A.C.Moressi 1978, carbon active Inc., New York.

Dixon, R.A. 1985. Plant Tissue Culture. A Practical Approach Series. Academic Press Inc. New York.

Gautheret, RJ 1955, 'The nutrition of plant tissue culture', Annu. Rev. Plant Physiol., 6 : (433 - 477)

George, E. F. and P. D. Sherington. 1984. Plant Propagantion by Tissue Cultur. P. D. Exegetis Limited. England.

Ginting 1990, 'Mengenal Anggrek Alam Indonesia', Penebar Swadaya Jakarta.

Gunadi 1985, Budidaya Anggrek Dendrobium. Penebar Swadaya Jakarta.

Gunawan, L. W. 1994. Teknik Kultur Jaringan Tumbuhan. Laboratorium Kultur Jaringan Pusat Antar Universitas Bioteknologi. Institut Pertanian Bogor.

Hartman, H.T., D. E. Kester and J.E. Davis. 1993. Plant propagation By Tissue Culture Handbook and Directory of Comercial Laboratories. New Jersey: Prantice-Hall International, Inc.

Harjadi. 2005. Studi aplikasi Sukrosa secara In Vitro. Departemen Budidaya Pertanian. Fakultas Pertanian. Institut Pertanian Bogor. Bogor.

2001, Petunjuk Praktis Merawat Anggrek 1. Agromedia. Jakarta.

Jenimar 1990, 'Pengaruh berbagai media kultur in vitro terhadap pertumbuhan planlet Anggrek Dendrobium', J. Hort., 14 (1) : 1-4

Jumiatul, A.2005. Aplikasi Beberapa Taraf Konsentrasi Kinetin Pada Berbagai Sumber Eksplan Khrisan secara Invitro. $\quad \mathrm{http} / / \mathrm{www}$. bdpunib.org;37 halaman.

Martin-Urdiroz, N, Garrido-Galo, J, Martin, J \& Barondiaran, X 2004, 'Effect of light on the organogenic ability of garlic roots using a one-step in vitro system', Plant Cell Rep., vol. 10, pp. $55-62$.

Nugroho. 2004. Pedoman Pelaksanaan Teknik Kultur Jaringan. Edisi Revisi. Penebar Swadaya. Jakarta.

Nugroho, A. dan Heru Sugito. 2001. Pedoman Pelaksanaan Teknik Kultur Jaringan. Penebar Swadaya. Jakarta.

Rismunandar. 1992. Hormon tanaman \& ternak, Penebar Swadaya. Jakarta.

Salisbury. F. B. dan C. W. Ross. 1995. Fisiologi Tumbuhan Jilid 3. Terjemahan oleh Lukman dan Sumariyono. ITB Bandung.

Sandra 2001, Merawat Anggrek. Penebar Swadaya Jakarta.

Sriwahyuni, D. 2006. Pengaruh Benih Semangka Tanpa Biji Terhadap Pemberian IAA dan Kinetin Pada Perbanyakan Secara In Vitro. Skripsi Jurusan Budidaya Pertanian. Fakultas Pertanian, Universitas Islam Riau. Tidak Diterbitkan.

Sriyanti, D.P. dan A. Wijayani. 1994. Teknik Kultur Jaringan. Yogyakarta 
Suskendriyati 2003, 'Pengaruh berbagai kombinasi suksrosa dan glukosa dalam media kultur in vitro terhadap pertumbuhan kultur jalus talinum paniculatum Gaertn. J. Hortikultura., 20 (1) : 1 - 4

Teo 1979, Teknik Perawatan Anggrek Dendrobium. IKIP Semarang Press. Semarang.

Wetherell, D. F. 1982. Pengantar Propagasi Tanaman Secara In Vitro. IKIP Semarang Press. Semarang.

Widiastoety, D \& Bahar, B 1994, 'Pengaruh berbagai konsentrasi sukrosa dalam media kultur in vitro terhadap pertumbuhan planlet Oncidium', J. Hortikultura.,

Widiastoety, D, Santi A, \& Solvia N, 2012, 'Pengaruh myoinositol dan arang aktif terhadap pertumbuhan planlet anggrek dendobium dalam kultur in vitro, Jurnal Hortikultura. Balai Benih Tanaman Hias. Cianjur.

Wijayani, A. 1994. Teknik Kultur Jaringan, Kanisius ( anggota ikpi), Yogyakarta

Yuliarti, N. 2010. Kultur Jaringan Tanaman Skala Rumah Tangga. Lily Publisher. Yogyakarta.

Yunus, A. 2007. Pengaruh IAA dan Kinetin Terhadap Pertumbuhan Eksplan Bawang Merah (Alliun ascalonium L.) Secara In - vitro. Jurnal Akta Agrosia $1: 53-58$.

Yusnita. 2003. Kultur Jaringan Cara Memperbanyak Tanaman Secara Efisien. Agromedia Pustaka, Jakarta.

Zulkarnain. 2009. Kultur Jaringan Tanaman. PT Bumi Aksara. Jakarta. 